Uji Efektivitas Sifat Hepatoprotektor Ekstrak Bawang Lanang - Harianto, dkk Jurnal Pangan dan Agroindustri Vol.6 No.4: 1-10 Oktober 2018

\title{
UJI EFEKTIVITAS SIFAT HEPATOPROTEKTOR EKSTRAK BAWANG LANANG PADA TIKUS WISTAR JANTAN YANG DIINDUKSI PARASETAMOL
}

\section{The Effectiveness Hepatoprotector of Single Clove Garlic Extract against Paracetamol Induced Hepatotoxicity in Male Wistar Rats}

\author{
Christine Eka Wulandari Harianto*, Tabita Hasian, Tri Dewanti Widyaningsih \\ Jurusan Teknologi Hasil Pertanian, FTP Universitas Brawijaya Malang \\ Jl. Veteran, Malang 65145 \\ *Penulis korespondensi, email: charianto10@gmail.com
}

\begin{abstract}
ABSTRAK
Hati merupakan salah satu organ penting yang bertanggung jawab dalam melaksanakan proses metabolisme obat. Parasetamol merupakan obat yang sering digunakan oleh masyarakat untuk penyembuhan penyakit. Parasetamol dapat memberikan efek berbahaya bagi tubuh, jika dikonsumsi dalam dosis berlebih dan dalam jangka waktu lama berupa kerusakan hati. Bawang lanang (Allium sativum L.) mengandung dua senyawa organosulfur utama yaitu $\gamma$-glutamyl-Sallyl-L-cysteines dan S-allyl-L-cysteine sulfoxides (allin). Hal ini menjadikan peluang tanaman tersebut dikembangkan menjadi ekstrak untuk kerusakan hati. Tujuan dari penelitian ini adalah untuk mengetahui efektivitas pemberian ekstrak bawang lanang terhadap pencegahan kerusakan dan penyembuhan hepar akibat konsumsi parasetamol berlebih pada tikus wistar jantan. Penelitian ini menggunakan desain penelitian True Experimental Design, Pre and Post Test Only Control Group Design dengan metode penelitian RAK menggunakan 7 kelompok perlakuan. Data dianalisis dengan ANOVA dan apabila terjadi perbedaan antar perlakuan, maka dilanjutkan dengan uji beda nyata yaitu BNT dengan selang kepercayaan $\alpha=5 \%$.
\end{abstract}

Kata Kunci: Bawang Lanang, Kerusakan Hepar, Parasetamol

ABSTRACT

Hepar is one of important organs responsible in drugs metabolism. Paracetamol commonly used by people to cure diseases. Paracetamol can provide harmful effects to the body, if consumed in large doses and long term. Single clove garlic (Allium Sativum L.) containing two organosulfur compounds which are $\gamma$-glutamyl-S-allyl-L-cysteines and S-allyl-L-cysteine sulfoxides (allin). Damage treatment of hepar still use chemical medicine has side effects. It makes opportunity to plant developed into extract for hepatic damage. The purpose of this research was to determine the effectiveness of single clove garlic extract as prevention and heal the liver due to excessive paracetamol consumption in male wistar rats. This research used True Experimental Design, Pre and Post Test Only Control Group Design, with CRD research method. Data were analyzed by ANOVA and if there was a difference between the treatments, then continued with the real difference test which was using SRD with the confidence interval $\alpha=5 \%$.

Keywords: Hepar Damage, Paracetamol, Single Clove Garlic Extract

\section{PENDAHULUAN}

Hepar merupakan salah satu organ penting yang berfungsi sebagai agen detoksifikasi dan penyimpan senyawa-senyawa racun serta organ yang sangat bertanggung jawab dalam 
melaksanakan proses metabolisme obat terutama obat-obatan yang diberikan melalui oral, salah satunya parasetamol yang berlebihan dalam tubuh (Silaban, 2012). Sebenarnya dalam dosis terapeutik, penggunaan parasetamol tidak menimbulkan bahaya. Efek yang berbahaya muncul pada dosis berlebihan dan dalam jangka waktu lama berupa kerusakan hepar (Dalimartha, 2005). Pencegahan kerusakan hepar oleh parasetamol dapat dilakukan dengan memakai obat tersebut dalam dosis yang dianjurkan serta mengonsumsi bahan pangan yang memiliki senyawa antioksidan yang berkhasiat sebagai hepatoprotektor seperti kurkumin, bawang putih dan bawang lanang. Menurut penelitian Marinda (2014), efek kurkumin sebagai antioksidan mampu menangkap ion superoksida dan memutus rantai antar ion superoksida $\left(\mathrm{O}^{2-}\right)$ sehingga mencegah kerusakan sel hepar. Kurkumin juga mampu meningkatkan gluthation S-transferase (GST) dan mampu menghambat beberapa faktor proinflamasi, ekspresi gen dan replikasi virus hepatitis $B$ melalui down regulation dari PGC-1 $\alpha$, sehingga dapat disimpulkan bahwa kurkumin dapat dijadikan alternatif hepatoprotektor pada pasien hepatitis kronis.

Bawang lanang atau bawang putih tunggal (Allium sativum L.) merupakan bawang yang hanya memiliki satu siung dalam satu umbi. Bawang ini dipercaya masyarakat Jawa sebagai salah satu obat tradisional atau jamu yang dapat mengobati penyakit liver (Hidayati, 2007). Pada dasarnya bawang lanang memiliki kandungan yang sama dengan bawang putih biasa, yaitu mengandung dua senyawa organosulfur utama yaitu $\gamma$-glutamyl-S-allyl-L-cysteines yang larut air dan S-allyl-L-cysteine sulfoxides (aliin) yang bersifat volatil. Harahap dkk (2004), dalam penelitian perbandingan daya hepatoprotektor bawang putih, bawang merah dan bawang prey berdasarkan pembakuan kandungan senyawa sulfhidril menyatakan pemberian sari air bawang putih memberikan efek protektif paling baik dibandingkan dengan sari air bawang merah dan bawang prey. Keadaan ini sesuai dengan kandungan gugus sulfihidril yang lebih tinggi dalam $1 \mathrm{ml}$ sari air bawang putih dibandingkan dengan dalam sari air bawang merah dan bawang prey. Berdasarkan hasil penelitian Banuriawan (2016), diketahui bahwa bawang lanang memberikan hasil yang lebih unggul dibandingkan dengan bawang putih biasa. Perlakuan terbaik dengan lama ekstraksi perendaman 6 jam memiliki aktivitas antioksidan $I_{50}$ sebesar 212,169 ( $\left.\mu \mathrm{g} / \mathrm{ml}\right)$, aktivitas antioksidan sebesar 3,79 ppm, total fenolik sebesar 238,6 mg GAE/g dan total flavonoid sebesar $656,4 \mathrm{mg} \mathrm{QE} / \mathrm{g}$. Pada penelitian terdahulu yang dilakukan oleh Harahap dkk (2004) efek hepatoprotektif terlihat pada pemberian sari air bawang putih sebesar $10 \mathrm{~g} / \mathrm{kg} \mathrm{BB}$.

Untuk membandingkan efek protektif antara kurkumin, bawang putih, dan bawang lanang, kepada tikus percobaan dilakukan analisis berupa pengukuran aktivitas enzim SGPT (Serum Glutamic Pyruvic Transaminase), enzim SGOT (Serum Glutamic Oxaloacetic Transaminase), kadar SOD (Superoxida Dismutase), kadar MDA (Malondialdehid), dan Histopatologi Hepar.

\section{BAHAN DAN METODE}

\section{Bahan}

Untuk penelitian ini digunakan tikus jantan galur wistar, yang berusia 3 bulan dengan berat badan sekitar 150-200 gram. Sebelum diberikan perlakuan tikus diadaptasikan terlebih dahulu di dalam laboraturium Nutrisi Pangan FTP UB selama 7 hari.

Bahan baku yang digunakan adalah bawang lanang dan bawang putih yang diperoleh dari Pasar Belimbing, Malang. Suplemen kurkumin dan parasetamol yang diperoleh di apotek Kimia Farma. Bahan-bahan kimia yang digunakan dalam penelitian ini adalah DPPH (2,2-difenil1-pikrilhidrazil), larutan $\mathrm{Na}_{2} \mathrm{CO}_{3}$, reagen Follin Ciocalteau, reagen $\mathrm{NaNO}_{2} 5 \%, \mathrm{AlCl}_{3} .6 \mathrm{H}_{2} \mathrm{O} 10 \%$, $\mathrm{NaOH} 1 \mathrm{M}$, asam galat standart, dan kuersetin standart untuk analisis kandungan bawang lanang. Untuk pengujian in vivo digunakan klorofom, formalin, pakan Susupap, Reagen kit (SGPT, SGOT, SOD, dan MDA), dan zat warna (hematoksilin dan eosin). 


\section{Alat}

Peralatan yang digunakan dalam pembuatan ekstrak dan analisis ekstrak adalah glassware (tabung reaksi, erlenmeyer, beaker glass, pipet volume, gelas ukur, labu ukur dan pengaduk), timbangan analitik, blender, vortex, kain saring (kassa), dan spektrofotometer UVVis. Peralatan yang digunakan untuk pengujian in vivo antara lain kandang tikus berupa bak plastik berukuran $45 \mathrm{~cm} \times 35.5 \mathrm{~cm} \times 14.5 \mathrm{~cm}$, tutup kandang berukuran $36.5 \mathrm{~cm} \times 28 \mathrm{~cm} \times 15.5 \mathrm{~cm}$, tempat makan tikus, tempat minum tikus, timbangan digital, eppendorf tube, syringe dan alat sonde. Peralatan yang digunakan untuk analisis histopatologi hepar antara lain alat bedah, botol organ, tissue, beaker glass, dan papan bedah.

\section{Desain Penelitian}

Desain penelitian yang digunakan yaitu True Experimental Design: Pre and Post Test Only Control Group Design. Pre and Post Test Only Control Group memungkinkan peneliti melihat dan mengukur pengaruh pemberian ekstrak bawang lanang sebelum dan sesudah tikus diberi parasetamol. Sedangkan pemilihan objek penelitian untuk pengelompokan dan pemberian perlakuan menggunakan metode RAL (Rancangan Acak Lengkap), hal ini karena hewan coba, bahan ransum, tempat percobaan dan bahan penelitian lainnya bersifat homogen.

\section{Metode}

Ekstrak air bawang lanang dibuat dengan menimbang $50 \mathrm{~g}$ bawang lanang. Kemudian dikupas, dicuci dengan mengalir, lalu dilumatkan dengan aquades $50 \mathrm{ml}$ diekstraksi maserasi selama 6 jam. Setelah itu dipisahkan antara ampas dan ekstrak bawang lanang. Dilakukan analisis aktivitas antioksidan $\mathrm{IC}_{50}$, total fenol, dan total flavonoid.

Bawang lanang diberikan dalam 3 dosis berbeda yaitu $5 \mathrm{mg} / \mathrm{kg} \mathrm{BB}, 10 \mathrm{mg} / \mathrm{kg} \mathrm{BB}$, dan 15 $\mathrm{mg} / \mathrm{kg} \mathrm{BB}$. Bawang putih diberikan sebesar $10 \mathrm{mg} / \mathrm{kg}$ BB. Kurkumin diberikan sebesar $50 \mathrm{mg} / \mathrm{kg}$ BB. Parasetamol diberikan dalam dosis $750 \mathrm{mg} / \mathrm{kg} \mathrm{BB}$. Percobaan ini diperlukan 28 ekor tikus yang dibagi secara acak menjadi 7 kelompok perlakuan. Kelompok 1 merupakan kontrol negatif dimana tikus hanya diberikan pakan standard dan aquades. Kelompok 2, 3, 4 merupakan kelompok perlakuan ekstrak bawang dengan 3 dosis berbeda. Kelompok 5 merupakan kelompok kontrol positif dimana tikus diberikan parasetamol. Kelompok 6 merupakan perlakuan pemberian kurkumin dan kelompok 7 perlakuan pemberian bawang putih.

Penelitian ini dilakukan selama 29 hari. Dimana 14 hari pertama kelompok perlakuan hanya diberikan ekstrak bawang lanang, bawang putih dan kurkumin. Kemudian pada 15 hari berikutnya kelompok perlakuan diberikan parasetamol namun tetap diberikan ekstrak bawang lanang, bawang putih dan kurkumin.

\section{HASIL DAN PEMBAHASAN}

Hasil analisis antioksidan $\mathrm{IC}_{50}$ ekstrak bawang lanang sebesar $65.074 \mu \mathrm{g} / \mathrm{ml}$. Hasil analisis total fenol $544.26 \mathrm{mg} \mathrm{GAE} / \mathrm{g}$ dan total flavonoid sebesar $218.315 \mathrm{mg}$ QE/g. Utami, dkk (2013) menyatakan bahwa senyawa asam amino yang mengandung sulfur (organosulfur) pada bawang lanang lebih tinggi dibandingkan dengan bawang putih biasa karena pada bawang lanang menghasilkan fotosintat yang terkumpul pada satu siung saja, sedangkan pada bawang putih biasa hasil fotosintat terbagi untuk siung-siung yang terbentuk sehingga menyebabkan kandungan senyawa organosulfur pada bawang putih biasa lebih sedikit dibandingkan dengan bawang lanang.

Berdasarkan hasil rerata berat badan tikus wistar jantan selama 29 hari. Kelompok perlakuan pemberian ekstrak bawang lanang memiliki berat badan yang lebih besar dibandingkan kelompok perlakuan lain. Hal ini dikarenakan pada perlakuan bawang lanang (Allium sativum L.) bersifat sebagai growth promotor. Zat yang diduga berfungsi sebagai growth promotor adalah scordinin. Pengaruh fisiologis scordinin yang disuntikkan pada tikus ternyata mampu 
meningkatkan pertumbuhan dan berat badan dibanding kontrol (Wibowo, 1989). Ali et al. (2008) juga menyatakan allicin yang terkandung dalam bawang lanang mengatur performa mikroorganisme dalam usus sehingga memperbaiki pencernaan makanan sehingga meningkatkan penggunaan energi yang selanjutnya meningkatan pertumbuhan.

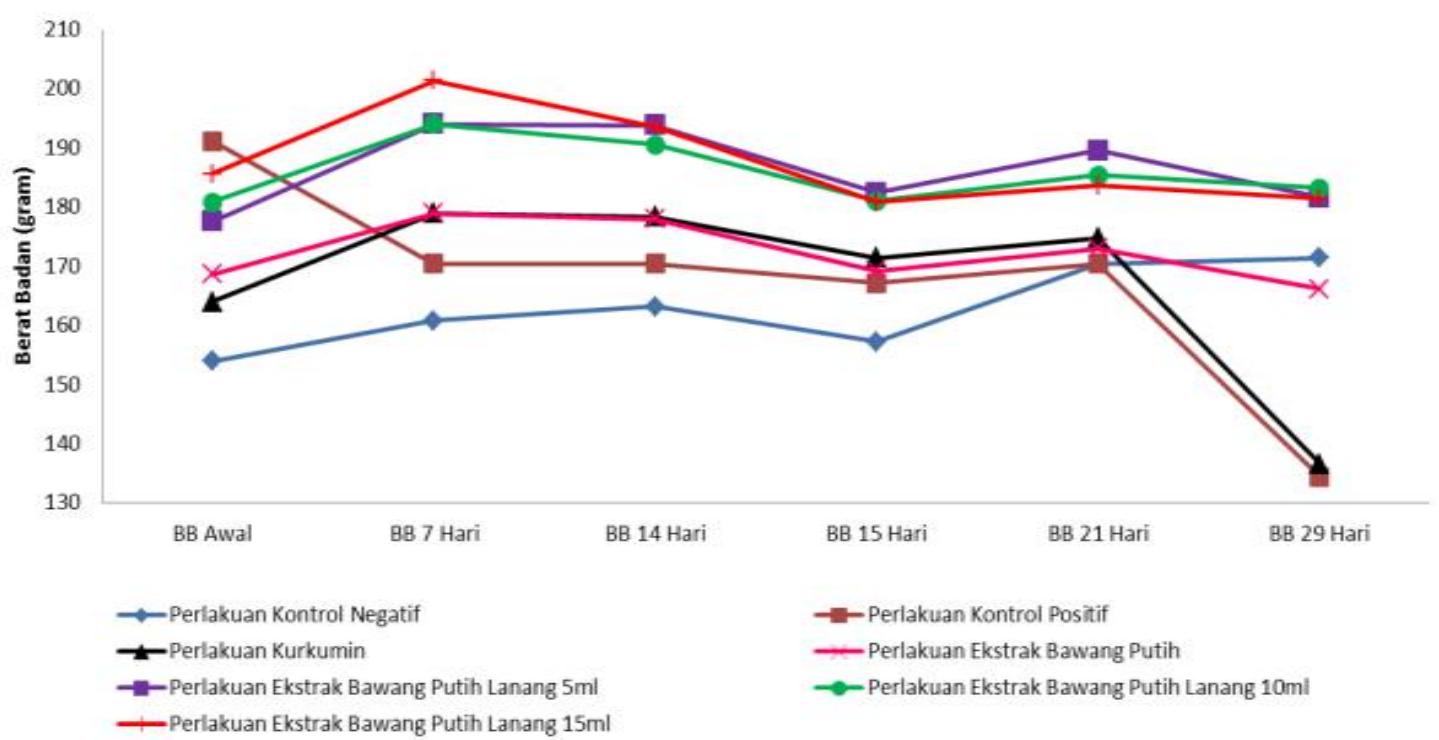

Gambar 1. Rerata Berat Badan Tikus Wistar

\section{SGPT (Serum Glutamic Pyruvic Transaminase)}

Serum Glutamic Pyruvic Transaminase (SGPT) terdapat pada sitosol hati dan merupakan salah satu indikator adanya gangguan pada organ hati. Konsentrasi enzim ini akan meningkat drastis apabila timbul beberapa macam kerusakan hati, seperti pada hepatitis karena virus, hepatitis alkoholik dan tumor hati (Stockham and Scott, 2008). Enzim ini akan keluar dari sel hepar apabila sel hepar mengalami kerusakan sehingga dengan sendirinya akan menyebabkan peningkatan konsentrasi dalam serum darah (Fauci et al., 2005).

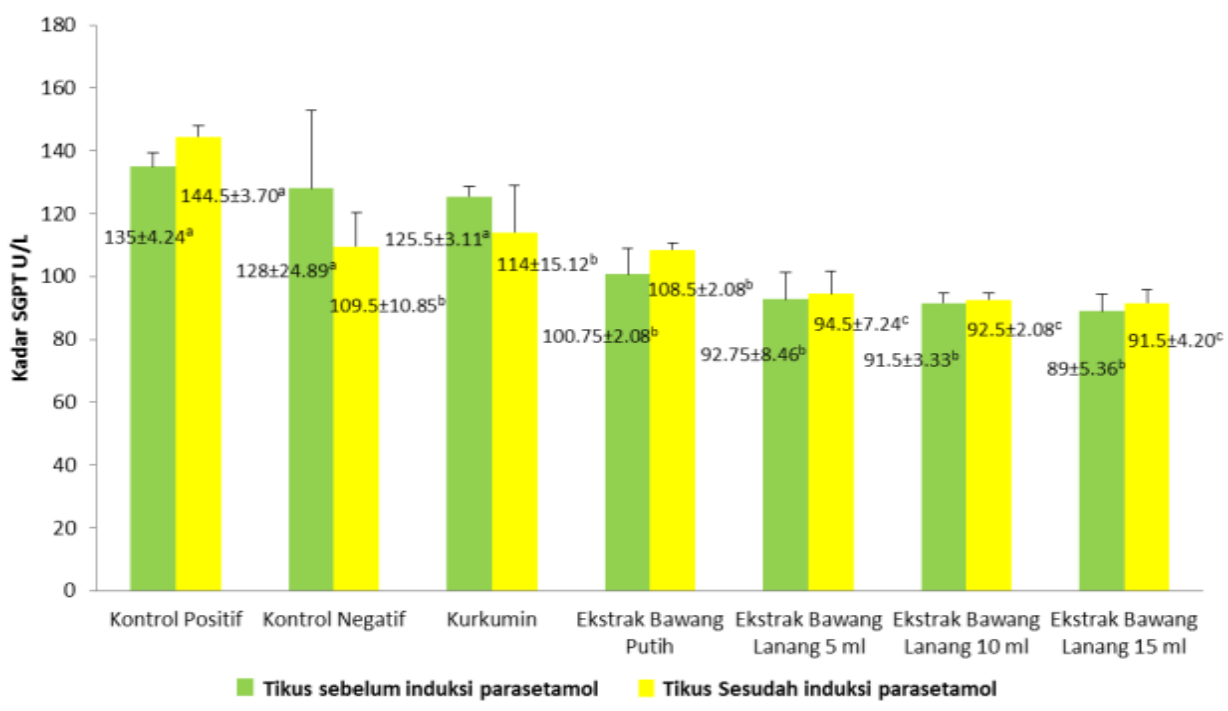

Gambar 2. Grafik SGPT (Serum Glutamic Pyruvic Transaminase) 
Berdasarkan hasil pengujian kadar enzim SGPT menunjukkan bahwa ekstra bawang lanang dengan 3 dosis berbeda mampu menurunkan kadar SGPT dibandingkan dengan perlakuan lainnya. Sebelum perlakuan pemberian parasetamol ekstrak bawang lanang dengan dosis $15 \mathrm{mg} / \mathrm{kg}$ BB mampu menurunkan kadar SGPT lebih rendah hal ini membuktikan ekstrak bawang lanang memberikan efek proteksi lebih tinggi. Bawang lanang mengandung senyawa polifenol yang diketahui aktif sebagai senyawa yang bertanggung jawab untuk memicu sistem imun tubuh (Effendi dkk, 2014).

Pada perlakuan setelah pemberian parasetamol dengan dosis $750 \mathrm{mg} / \mathrm{kg}$ BB terjadi kerusakan hati terlihat peningkatan aktivitas enzim Glutamat Piruvat Transminase (GPT) dan penurunan kadar glutation. Pemberian ekstrak bawang lanang pada tikus yang diberi parasetamol, ternyata memperlihatkan perbaikan fungsi hepar. Pada kerusakan hati tidak terlihat peningkatan aktivitas enzim GPT yang berarti dan juga ada perbaikan kandungan glutation dalam hati. Senyawa organosulfur dalam ekstrak AGE (Aged Garlic Extract) umbi bawang lanang, yaitu S-allyl-cysteine (SAC) dan S-allyl-mercapto- cysteine (SAMC), mampu menghambat oksidasi yang disebabkan senyawa chemiluminescense dan mencegah pembentukan senyawa asam tiobarbiturat reaktif dalam hati (Imai et al.,1994).

\section{SGOT (Serum Glutamic Oxaloacetic Transminase)}

Serum Glutamic Oxaloacetic Transminase (SGOT) merupakan suatu enzim dalam tubuh yang segera terdeteksi dalam sirkulasi perifer apabila terjadi trauma atau nekrosis pada suatu jaringan. Kadar SGOT pada pemeriksaan laboratoris dapat digunakan untuk menilai seberapa luas kerusakan hati namun SGOT juga banyak ditemukan pada jaringan selain hati namun tidak menutup kemungkinan perubahan SGOT juga terjadi akibat penyakit jantung (Qodriyati dkk, 2016). Enzim SGOT berada di sel hati dan organ lain. SGOT dikeluarkan kedalam darah ketika hati rusak.

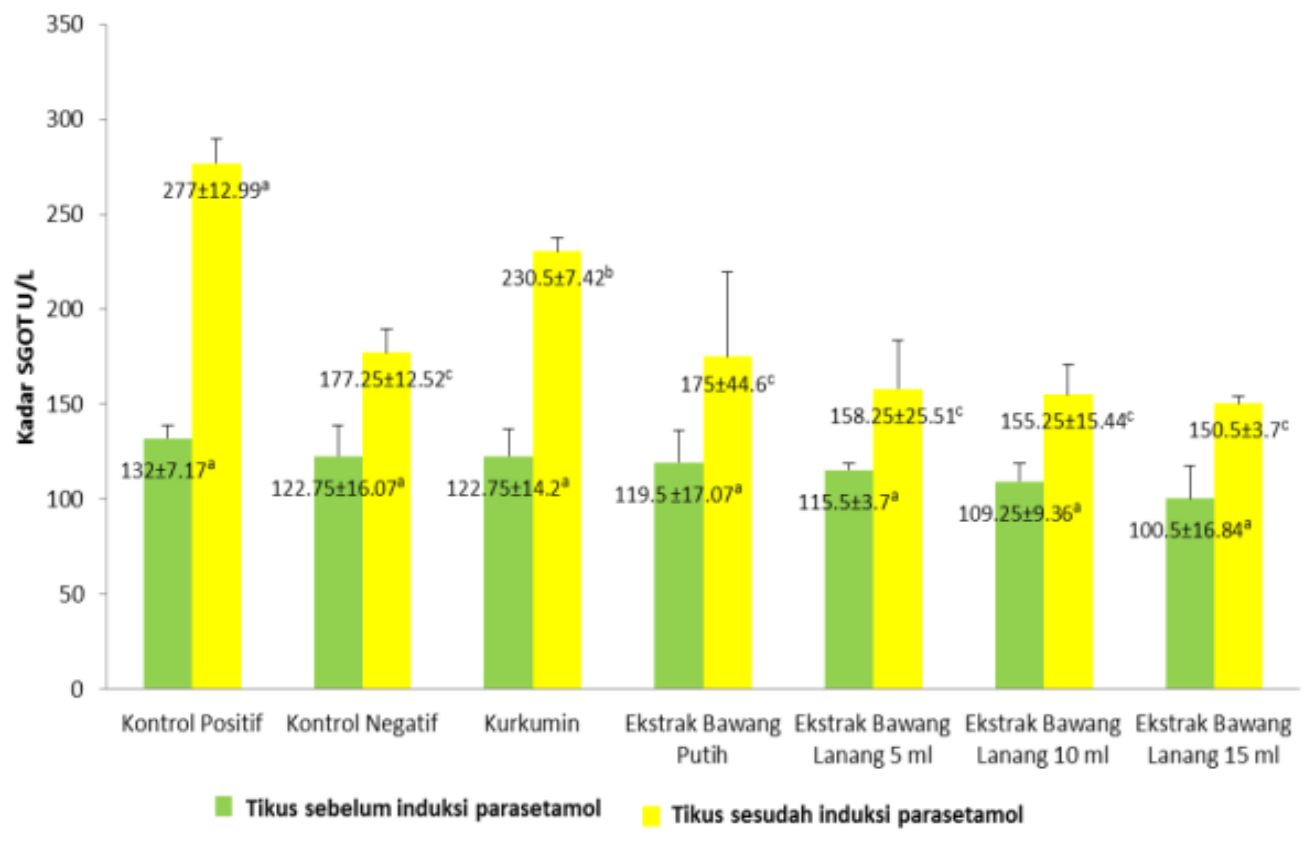

Gambar 3. Grafik SGOT (Serum Glutamic Oxaloacetic Transminase)

Berdasarkan hasil pengujian kadar enzim SGOT menunjukkan bahwa ekstrak bawang lanang memberikan efek proteksi lebih tinggi dibandingkan kurkumin dan ekstrak bawang putih 
biasa. Selain memberikan efek proteksi lebih tinggi, ekstrak bawang lanang mampu meningkatkan respon imun dan pertumbuhan dari tikus wistar. Senyawa kimia dalam umbi ini dapat mendorong aktivitas makrofage dan sel $\mathrm{T}$, serta efektif dalam mengatasi infeksi virus pada saluran pernapasan atas dan melindungi membran sel untuk mencegah rusaknya DNA (Holladay, 1997). Bawang lanang mengandung alliin atau asam amino dan multivitamin sehingga dapat meningkatkan kesehatan yang mencegah terjadinya mortalitas atau kematian yang tinggi (Suhartati, 2004).

Pada perlakuan setelah pemberian parasetamol mengalami kenaikan kadar SGOT hal ini dikarenakan tikus sakit yang diinduksi parasetamol, terkena dampak negatif ROS (Reactive Oxygen Species) dari parasetamol. Dampak negatif ROS (Reactive Oxygen Species) dapat merusak komponen sel yang sangat penting karena ROS (Reactive Oxygen Species) dapat bereaksi dengan lemak, protein, dan DNA. Reaksi antar ROS (Reactive Oxygen Species) dengan lemak tak jenuh pada membran sel dapat menghasilkan senyawa peroksida yang berpotensi menyebabkan kerusakan pada membran sel sehingga enzim-enzim sitoplasma keluar ke dalam peredaran darah. ROS (Reactive Oxygen Species) yang sangat reaktif ini dapat berikatan dengan DNA pada mitokondria sehingga menyebabkan nekrosis sel. Nekrosis sel yang terjadi pada sel hepatosit akan menyebabkan enzim GOT keluar ke peredaran darah sehingga dapat menyebabkan peningkatan kadar SGOT (Maslachah dkk., 2008). Ekstrak bawang lanang mampu menurunkan kadar SGOT pada tikus yang telah diberikan parasetamol dengan dosis toksis. Menurut penelitian tentang perbandingan daya hepatoprotektor pada bawang putih yang dilakukan Harahap dkk (2004) pemberian sari bawang putih memberikan efek protektif paling baik dibandingkan dengan sari air bawang merah dan bawang prey. Keadaan ini sesuai dengan kandungan gugus sulfihidril yang lebih tinggi pada ekstrak bawang putih.

\section{MDA (Malondialdehyde)}

MDA adalah suatu senyawa yang sangat reaktif yang merupakan produk akhir dari peroksidasi lipid, dan biasanya digunakan sebagai biomarker biologis peroksidasi lipid untuk menilai stres oksidatif (Timbrell, 2002).

Tabel 1. Kadar Malondialdehyde (MDA)

\begin{tabular}{lccc}
\hline \multicolumn{1}{c}{ Perlakuan } & \multicolumn{2}{c}{ Kadar MDA (ng/ml) } & $\begin{array}{c}\text { Persentase Kenaikan } \\
\text { Kadar MDA (\%) }\end{array}$ \\
\cline { 2 - 3 } & Awal & Akhir & $2.54^{\mathrm{b}}$ \\
\hline Kontrol Negatif (aquades) & 4.17 & 4.27 & $35.84^{\mathrm{c}}$ \\
Kontrol Positif & & 6.67 & $20.04^{\mathrm{a}}$ \\
Kurkumin 50 mg / kg BB & 3.82 & 4.78 & $19.79^{\mathrm{a}}$ \\
Ekstrak Bawang Putih 10 g/kg BB & 3.94 & 4.92 & $19.31^{\mathrm{a}}$ \\
Ekstrak Bawang Lanang 5 g/kg BB & 3.69 & 4.57 & $18.16^{\mathrm{a}}$ \\
Ekstrak Bawang Lanang 10 g/kg BB & 3.57 & 4.36 & $17.38^{\mathrm{a}}$ \\
Ekstrak Bawang Lanang 15 g/kg BB & 3.41 & 4.12 & \\
\hline
\end{tabular}

Keterangan: notasi huruf yang sama menunjukkan tidak beda nyata $(\alpha=0.05)$

Berdasarkan hasil pengujian kadar MDA serum darah tikus, dapat diketahui bahwa ekstrak bawang lanang baik dosis $5 \mathrm{mg} / \mathrm{kg} \mathrm{BB}, 10 \mathrm{mg} / \mathrm{kg} \mathrm{BB}$, dan $15 \mathrm{mg} / \mathrm{kg}$ BB memiliki persentase kenaikan yang cenderung lebih rendah dibandingkan dengan kelompok kontrol positif dan kelompok perlakuan kurkumin serta bawang putih. Persentase peningkatan kadar MDA juga menunjukkan persen peningkatan yang semakin kecil seiring dengan meningkatnya dosis ekstrak bawang lanang. Hal tersebut menunjukkan bahwa semakin tinggi dosis ekstrak bawang lanang yang diberikan maka peningkatan kadar MDA yang terjadi setelah diberikan parasetamol dosis toksik juga semakin kecil.

Tingginya kadar MDA menunjukkan tingginya kandungan radikal bebas di dalam tubuh hewan coba. Dagli dkk (2004) dalam penelitiannya tentang polip hidung dalam hubungannya 
dengan radikal bebas dan malondialdehid (MDA), didapatkan bahwa semakin tinggi kadar radikal bebas maka makin tinggi kadar malondialdehid (MDA) dalam tubuh. Hal tersebut menunjukkan bahwa bawang lanang lebih efektif dalam menangkal pembentukan radikal bebas akibat konsumsi parasetamol dosis toksik.

\section{SOD (Superoxyde Dismutase)}

Tabel 2. Kadar Superoxyde Dismutase (SOD)

\begin{tabular}{lcccc}
\hline \multirow{2}{*}{ Perlakuan } & \multicolumn{2}{c}{ Kadar SOD (unit/ml) } & \multirow{2}{*}{$\begin{array}{c}\text { Persentase } \\
\text { Penurunan Kadar } \\
\text { SOD (\%) }\end{array}$} \\
\cline { 2 - 3 } & Awal & Akhir & SOD (\%.05 \\
\hline Kontrol Negatif (aquades) & 6.77 & 6.60 & $4.05^{\mathrm{b}}$ \\
Kontrol Positif & 7.25 & 2.70 & $60.34^{\mathrm{c}}$ \\
Kurkumin 50 mg / kg BB & 7.72 & 5.20 & $28.34^{\mathrm{d}}$ \\
Ekstrak Bawang Putih 10 g/kg BB & 8.57 & 7.05 & $33.85^{\mathrm{e}}$ \\
Ekstrak Bawang Lanang 5 g/kg BB & 8.44 & 7.99 & $17.73^{\mathrm{a}}$ \\
Ekstrak Bawang Lanang 10 g/kg BB & 9.44 & $15.30^{\mathrm{a}}$ \\
Ekstrak Bawang Lanang 15 g/kg BB & 10.03 & 8.79 & $10.83^{\mathrm{f}}$ \\
\hline
\end{tabular}

Keterangan: notasi huruf yang sama menunjukkan tidak beda nyata $(\alpha=0.05)$

Berdasarkan hasil pengujian kadar SOD serum darah tikus wistar jantan, dapat diketahui bahwa pemberian ekstrak bawang lanang dengan 3 dosis yang berbeda memiliki persentase penurunan kadar SOD akibat parasetamol dosis toksik yang lebih kecil dari pada kelompok perlakuan lainnya. Adanya induksi parasetamol dosis $750 \mathrm{mg} / \mathrm{kg}$ BB akan memicu terbentuknya senyawa radikal bebas atau ROS (Reactive Oxygen Species) yang akan menyebabkan kondisi stress oksidatif. Menurut Suarsana dkk. (2013), stress oksidatif dapat menurunkan kadar superoksida dismutase dan meningkatkan terbentuknya senyawa radikal bebas atau ROS (Reactive Oxygen Species) sehingga membran sel dapat mengalami kerusakan serta enzimenzim tertentu akan keluar dari sel akibat rusaknya sistem membran sel menuju ke plasma darah, seperti ALT (Alanin Amino Transferase) dan AST (Alanin Aspartat Transferase). Hal ini memaksa SOD sebagai antioksidan primer di dalam tubuh bereaksi dengan cara menetralisir senyawa radikal bebas yang terbentuk sehingga kadar SOD dalam tubuh akan terus berkurang jika tubuh tidak mendapatkan tambahan antioksidan dari luar.

Pada kelompok perlakuan ekstrak bawang lanang dengan 3 dosis berbeda mampu memberikan perlindungan cukup efektif terhadap paparan stress oksidatif akibat pemberian parasetamol dosis toksik. Hal tersebut ditunjukkan dari rata-rata persentase penurunan kadar SOD kelompok perlakuan ekstrak bawang lanang yang lebih kecil daripada persentase jumlah penurunan kadar SOD pada kelompok kontrol positif. Arief (2000) menjelaskan bahwa pemberian senyawa antioksidan yang semakin tinggi akan meningkatkan kadar antioksidan endogen yang dapat membantu dalam menetralisir radikal bebas.

\section{Histopatologi Hepar}

Hasil pengamatan preparat pewarnaan $\mathrm{HE}$ organ hati yang diberi parasetamol menunjukkan adanya perbedaan pada histopatologi antar perlakuan. Sel hepar tikus yang dipapar parasetamol dosis toksik secara terus-menerus akan mengalami kerusakan sel yang ditandai dengan inti sel menyusut, dan berwarna gelap dengan zat warna HE. Berdasarkan literatur, kerusakan hepar yang berupa nekrosis dapat terjadi sebagai akibat dari pemberian parasetamol dengan dosis yang berlebihan (dosis toksik), umumnya perubahan-perubahan yang terjadi pada sel nekrotik dapat terjadi pada semua bagian sel tetapi perubahan pada inti sel adalah petunjuk yang paling jelas pada kematian sel (As'ari, 2009). Bagian sel yang telah mati 
intinya menyusut, batas tidak teratur, dan berwarna gelap dengan zat warna yang biasa digunakan oleh para ahli patologi anatomi. Proses ini dinamakan piknosis dan intinya disebut piknotik (Price and Wilson, 1994). Struktur histologis hepar tikus yang normal pada hepatosit bisa dijumpai adanya satu inti atau beberapa inti di tengah sel. Nukleus terlihat jelas struktur dan batasnya. Permukaan tiap hepatosit berhubungan dengan sinusoid atau hepatosit lain (Mulyono, dkk., 2009).
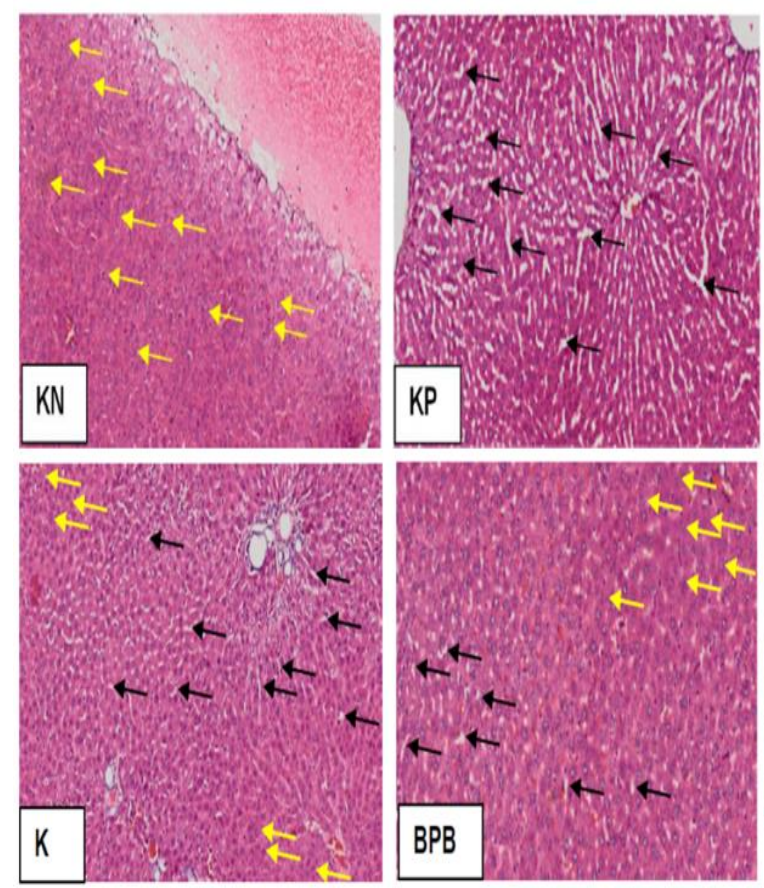
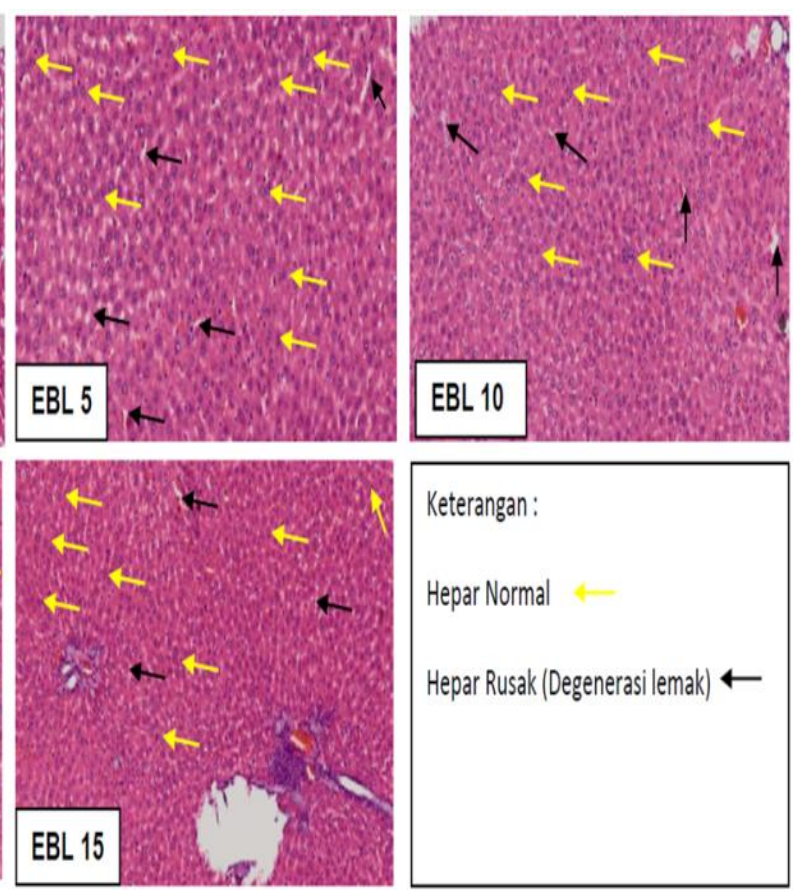

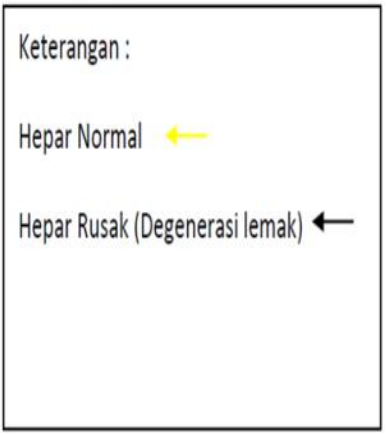

Gambar 4. Histopatologi Hepar Tikus Wistar yang Terdiri dari (KP) Tikus Sakit; (KN) Tikus Sehat; (K) Perlakuan Kurkumin; (BPB) Perlakuan Bawang Putih; (EBL 5) Perlakuan Bawang Lanang Dosis 5mg/kgBB; (EBL 10) Perlakuan Bawang Lanang Dosis 10mg/kgBB; (EBL 15) Perlakuan Bawang Lanang Dosis $15 \mathrm{mg} / \mathrm{kgBB}$

Pada hepar tikus yang diberikan ekstrak bawang lanang dengan dosis $15 \mathrm{mg} / \mathrm{kg}$ BB menunjukan sel hepar yang hampir sama dengan sel hepar normal. Hal tersebut menunjukkan bahwa bawang lanang memberikan kemampuan yang lebih baik dalam menekan jumlah sel yang mengalami nekrosis dibandingkan dengan kelompok dengan tambahan asupan antioksidan lainnya. Senyawa organosulfur dalam ekstrak AGE (aged garlic extract) umbi bawang lanang, yaitu S-Allyl-Cysteine (SAC) dan S-allyl-mercapto-cysteine (SAMC), mampu menghambat oksidasi yang disebabkan senyawa chemiluminescense dan mencegah pembentukan senyawa asam tiobarbiturat reaktif dalam hati (Imai et al., 1994). Senyawa SAC dan SAMC tersebut menginduksi sintesis GSH, tripeptidatiol yang melindungi sel dari kerusakan akibat radikal bebas (Shirin et al., 2001).

\section{SIMPULAN}

Hasil penelitian menunjukkan bahwa ekstrak air bawang lanang memiliki aktivitas antioksidan $\mathrm{IC}_{50}$ sebesar $65.074 \mu \mathrm{g} / \mathrm{ml}$, dengan jumlah total fenol sebesar $544.26 \mathrm{mg} \mathrm{GAE} / \mathrm{g}$ dan total flavonoid sebesar $218.315 \mathrm{mg} \mathrm{QE} / \mathrm{g}$. Pemberian ekstrak bawang lanang selama $2 \mathrm{minggu}$ pada tikus wistar jantan mampu meningkatkan kadar SOD menurunkan kadar MDA serum darah, 
menurunkan kadar SGPT dan SGOT. Pemberian ekstrak bawang lanang secara rutin pada tikus wistar jantan yang dipapar parasetamol dosis toksik mampu menekan peningkatan kadar MDA, SGPT dan SGPT serta mempertahankan kadar SOD didalam tubuh, serta mampu melindungi sel-sel hati dari kerusakan akibat paparan parasetamol dosis toksik.

\section{DAFTAR PUSTAKA}

Ali, S.M., Nashwa, M.A.A., and Mohamed, F.M. 2008. Effect of Garlic on The Survival, Growth, Resistance and Quality of Oreochromis niloticus. 8th International Symposium on Tilapia in Aquaculture.

Arief, A. 2000. Pengaruh Antioksidan Pada Tempe Kedelai Terhadap Kadar Superoxyde Dismutase dan Malondialdehyde Serum Tikus Wistar Dipapar Dengan Asap Rokok Subakut. Skripsi. Universitas Brawijaya. Malang.

As'ari, H. 2009. Efek Pemberian Madu Terhadap Kerusakan Sel Hepar Mencit (Mus musculus) Akibat Paparan Parasetamol. Skripsi. Universitas Sebelas Maret. Surakarta.

Banuriawan, T. 2016. Studi Komparasi Aktivitas Antioksidan Bawang Putih (Allium sativum L.) dengan Bawang Putih Tunggal Menggunakan Metode Ekstraksi dan Sonikasi (Kajian Pengaruh Lama Perendaman). Skripsi. Universitas Brawijaya. Malang.

Dagli, M., Eryilmaz, A., Besler, T., Akmansu, H., Acar, A., and Korkmaz, H. 2004. Role of Free Radicals and Antioxidants in Nasal Polyps. Laryngoscope 114: 1200-1203.

Dalimartha S. 2005. Ramuan Tradisional untuk Pengobatan Hepatitis. Swadaya. Jakarta.

Effendi, Nurmaya, Widiastuti, dan Harti., 2014. Identifikasi Aktivitas Imunoglobulin M (IG.M) Ekstrak Etanolik Daun Ceplukan (Physalis minima Linn.) Pada Mencit. Universitas Muslim Indonesia. Makassar.

Fauci A.S., dan Longo D.L. 2005. Jaundice and Evaluation of Liver Function. In: Kasper, D.L., Braunwald, E., Fauci, A.S., Hauser, S.L., Longo, D.L., and Jameson, J.L., editors. Harrison's Principles of Internal Medicine. 16th Edition. Mc Graw Hill. New York.

Harahap, Indriati P., Sadikin, M., Zulfiani, Kartina., dan Azizawati. 2004. Perbandingan Daya Hepatoprotektif Bawang Putih, Bawang Merah, dan Bawang Prey Berdasarkan Pembakuan Kandungan Senyawa Sulfhidril. Skripsi. Universitas Indonesia. Jakarta.

Hidayati, S. 2007. Peranan Antioksidan Bawang Putih (Allium sativum) sebagai Hepatoprotektor. Skripsi. Insitut Teknologi Bandung. Bandung.

Holladay, S. 1997. Garlic: The Great Protector. http://www.botanical.com/botanical/ article/garlic.htm. Tanggal akses: 23/05/2017

Imai, J., Ide, N., Nagae, S.T., Morigachi, H., Matsuura, and Itakura. Y. 1994. Antioxidant and Radical Scaveging Effects of Aged Garlic Extract and Its Constituents. Plant Medica 60:5, 417-420.

Maslachah L., Sugihartuti R., and Kurniasanti R. 2008. Hambatan Produksi Reactive Oxygen Species Radikal Superoksida $\left(\mathrm{O}^{2-}\right)$ Oleh Antioksidan Vitamin E ( $\alpha$-Tocopherol) pada Tikus Putih (Rattus norvegicus) yang Menerima Stressor Renjatan Listrik. Media Kedokeran Hewan 24:1, 21-26.

Marinda, F.D. 2014. Hepatoprotective Effect of Curcumin in Chronic Hepatitis. Jurnal Majority 3:7, 52-56.

Mulyono, A., Ristiyanto, dan Soesanti N. 2009. Karateristik Histopatologi Hepar Tikus GOT Rattus norvegicus Infektif Leptospira sp. Jurnal Vektora 1:2, 84-92.

Price, S.A., and Wilson L.M. 1994. Patofisiologi, Konsep Klinis Proses-proses Penyakit. Edisi 4. EGC. Jakarta. pp: 773-775.

Qodriyati, N.L.Y., Sulistyani E., dan Yuwono B. 2016. Kadar Serum Glutamic Oxaloacetic Transaminase (SGOT) pada Tikus Wistar (Rattus norvegicus) Jantan yang Dipapar Stresor Rasa Sakit Electrical Foot Shock selama 28 Hari. e-Jurnal Pustaka Kesehatan 4:1, 73-77. 
Shirin, H., Pinto, J. T., Kawabata, Y., Soh, J.-W., Delohery, T., Moss, S. F., Rivlin, R.S., Holt P.R., and Weinstein I.B. 2001. Antiproliferative Effects of S-allylmercaptocysteine on Colon Cancer Cells When Tested Alone or in Combination with Sulindac Sulfide. Cancer Research 61:2, 725-31.

Silaban, S. 2012. Uji Aktivitas Hepatoprotektor Ekstrak Air Pegagan (Centella asiatica) terhadap Tikus Putih Jantan yang Diinduksi Parasetamol. Skripsi. Institut Pertanian Bogor. Bogor.

Stockham S.L., and Scott M.A. 2008. Fundamentals of Clinical Veterinary Pathology. lowa State University Press. lowa.

Suarsana I.N., Wresdiyati T., and Suprayogi A. 2013. Respon Stres Oksidatif dan Pemberian Isoflavon terhadap Aktivitas Enzim Superoksida Dismutase dan Peroksidasi Lipid pada Hati Tikus. Jurnal IImu Ternak dan Veteriner 18:2, 146-152.

Timbrell, J. 2002. Principal of Biochemical Toxicology 3th Edition. Taylor and Francis, Inc. USA. Utami, Prapti dan Mardiana L. 2013. Umbi Ajaib Tumpas Penyakit. Penebar Swadaya. Jakarta Wibowo, S., 1989. Budi Daya Bawang Putih. Swadaya. Jakarta. 